\title{
Influence of a biological fungicide on the development and spreading of Alternaria alternata on vegetable crops
}

\author{
Oksana Kremneva*, Svetlana Nekoval, Alexey Pachkin, Anastasia Zakharchenko and \\ Ksenia Gasiyan
}

FSBSI «Federal Research Center of Biological Plant Protection», Krasnodar, 350039, Russia

\begin{abstract}
The effect of the biofungicide BFTIM KS-2, Zh on the development and spreading of the Alternaria alternata fungus on vegetable crops (tomato, pepper, eggplant) was studied using classical and modern methods of phytosanitary monitoring. The research was carried out in Krasnodar region in the Pavlovsky District, on the production fields of the ZAO Yubileinoye. To assess the development and spreading of the disease, the classical visual method was used, as well as a modern method for determining the congestion rate of plantings using the OZR-1mp spore trap.The article presents data on the development and spreading of $A$. alternata, the number of fungal spores on vegetable crops before and after treatments with the biofungicide. It was found that the use of the biological product reduces the development and spreading of the phytopathogen. Its influence is the most effective on tomato and eggplant crops. Also, in the course of research, the possibility of using a spore trap for monitoring Alternaria on vegetable crops has been shown.
\end{abstract}

\section{Introduction}

Vegetable crops provide the basis of the daily human diet, being a rich source of vitamins, enzymes, and mineral salts. Tomato (Solanum lycopersium Mill.), pepper (Capsicum annuum L.) and eggplant (Solanum melongena L.) all over the world, including Russia, are among the most cultivated and consumed vegetable crops [1-4]. So, for example, Krasnodar Krai is one of the leading regions of Russia in terms of area and production of tomato in open ground. In 2020, according to Rosstat, 893.4 thousand tons of tomato were produced in the industrial sector of vegetable growing in Russia on an area of 17.9 thousand hectares. In Krasnodar Krai, 9.08 thousand tons of tomato were produced on an area of 0.47 thousand hectares (ABCenter, 2020). Tomato, pepper and eggplant are highly susceptible to the influence of abiotic and biotic factors that affect the yield and product quality. These crops are damaged with up to 200 diseases caused by viruses, bacteria, nematodes and fungi. The most common and economically significant disease is considered to be alternaria, which is caused by Alternaria fungi $[5-10]$.

\footnotetext{
${ }^{*}$ Corresponding author: kremenoks@mail.ru
} 
To develop effective crop protection against economically significant pathogens, accurate phytosanitary monitoring is necessary [11], since not only a properly selected fungicide is important, but also its timely use at the initial stages of phytopathogen development [12]. One of the promising directions in the field of phytosanitary monitoring is the use of spore traps, since they are able to quickly and accurately quantify fungal phytopathogens in the air space around plantings [13]. Since the description of one of the first, the Hurst trap, models of spore traps have been constantly improving, which allows obtaining more complete information about the composition of phytopathogens in a short time, on the basis of which decisions on treatments are then made. [14]. When studying the effectiveness of various spore traps, it was found that the use of mobile traps is more effective for detecting phytopathogen spores in the air than the use of stationary ones. It has also been shown that observations based on mobile traps reveal a decrease in the number of airborne spores after the start of treatments [15].

The aim of the research was to study the effect of a biological fungicide on the development and spreading Alternaria alternata fungus on vegetable crops using classical and modern methods.

\section{Materials and methods}

The objects of research were the plantings of tomato, pepper and eggplant. Phytosanitary surveys of the plantings of the crops for signs of plant damage by alternaria (A. alternata species) were carried out from June 17 to July 02, 2020 in the Krasnodar region in Pavlovsky District, on the production fields of the ZAO Yubileinoye. Monitoring was carried out in two ways: classical - a visual assessment of the development and spreading of diseases according to the "Methodological guidelines for registration tests of fungicides in agriculture" [16] and modern - by determining the contamination of plants using the OZR-1mp device [17] according to the method described in the article «Development of technology for detecting foci of wheat rust diseases» [13]. The type of the alternaria pathogen was determined according to the key (2007) [18]. Sampling by the device was carried out in sunny calm weather. The sampling time was $30 \mathrm{sec}$. In total, 5 samples were taken from each studied crop (tomato, eggplant, pepper). The movement of the operator with the device was carried out along the diagonal of the field. The samples obtained were subjected to microscopic analysis. A print of one sample occupies $100 \mathrm{~mm}^{2}$ on glass and is presented in the form of a rectangle with dimensions of $20 \times 5 \mathrm{~mm}$. The number of spores was counted in the test strip (along the width of the field of view), which runs along the center of the print along its larger side.

\section{Results and discussions}

As a result, spores of the $A$. alternata fungus were detected on all studied crops using an air sampler (Fig. 1, Table 1). 


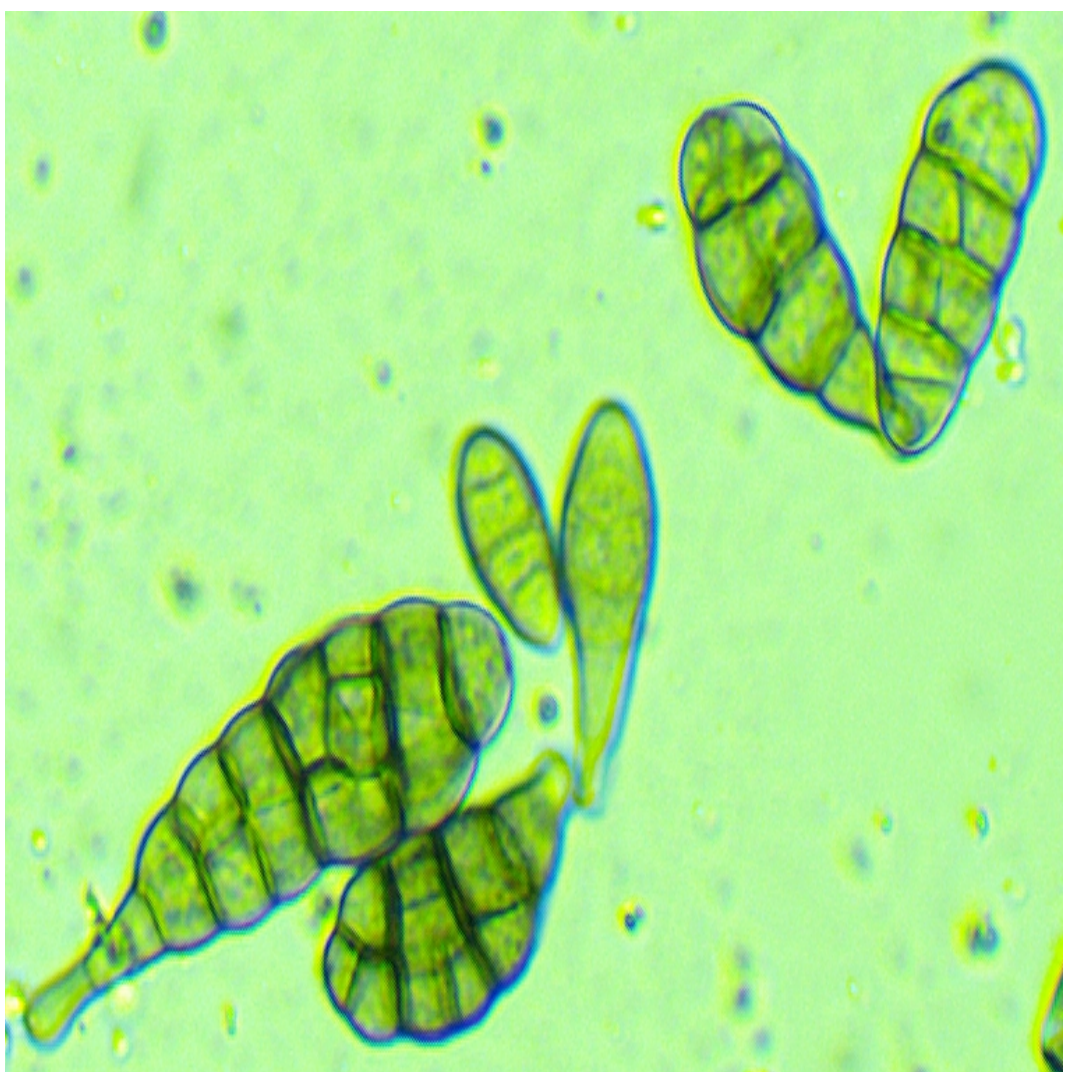

Fig. 1. A. alternata spores, caught with the air sampler on the vegetable crops

Table 1. The number of A. alternata spores detected using the OZR-1MP device on vegetable crops in open ground

\begin{tabular}{|c|c|c|}
\hline \multirow{2}{*}{ Date } & Crop & $\begin{array}{c}\text { Average number of } \text { A. alternata } \\
\text { spores per sample, pcs }\end{array}$ \\
\hline \multirow{3}{*}{17.06 .2020} & Tomato & $1.8 \pm 0.37$ \\
\cline { 2 - 3 } & Pepper & $2.2 \pm 0.58$ \\
\cline { 2 - 3 } & Eggplant & $2.2 \pm 0.58$ \\
\hline \multirow{3}{*}{25.06 .2020} & Tomato & $3 \pm 0.90$ \\
\cline { 2 - 3 } & Pepper & $0.4 \pm 0.24$ \\
\cline { 2 - 3 } & Eggplant & $2.6 \pm 0.75$ \\
\hline \multirow{3}{*}{02.07 .2020} & Tomato & $2.6 \pm 0.75$ \\
\cline { 2 - 3 } & Pepper & $0.4 \pm 0.24$ \\
\cline { 2 - 3 } & Eggplant & 0 \\
\hline
\end{tabular}

Before treatment on 17.06.2020, spores of the pathogen were found on all crops from 1.8 to 2.2 pcs per sample. After the second treatment on 02.07.2020, the number of spores on the tomato did not increase, on the pepper it decreased to 0.4 pcs., on the eggplant, no spores were found.

Visual observation of plants during the first monitoring revealed the development and spreading of alternaria (A. alternata) on different vegetable crops from 8 to $20 \%$ and from 5 to $30 \%$, respectively (Fig. 2). On June 17, 2020, treatment was carried out with the 
biofungicide BFTIM KS-2, Zh with a rate of application of $71 /$ ha. With the repeated monitoring on June 25, 2020, a decrease in the development and spreading of the disease was noted. In all the studied plantings, to maintain a stable phytosanitary situation, the treatment with biofungicide was repeated on June 26, 2020. This stopped the development and spreading of alternaria and promoted an active increase in plant biomass, which is confirmed by the monitoring results on July 02,2020 . The development of the disease in areas with tomato did not exceed $10 \%$, in areas with eggplant and pepper $-5 \%$.

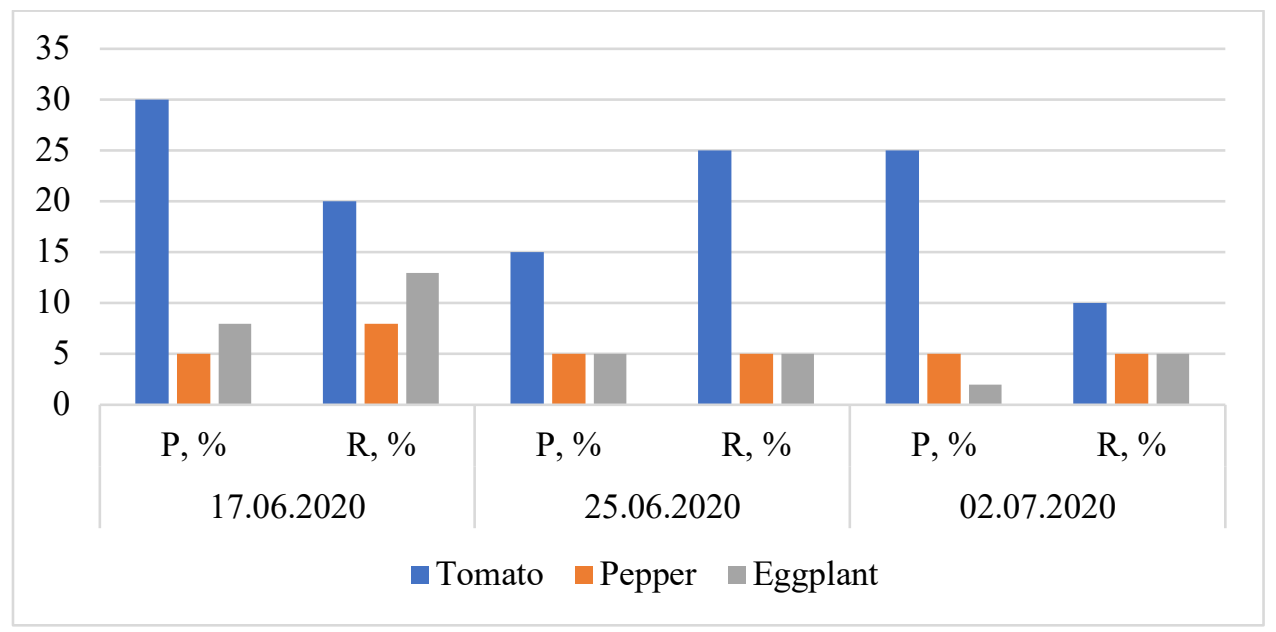

Fig. 2. Development and spreading of alternaria on the vegetable crops

\section{Conclusion}

The effect of the biofungicide BFTIM KS-2, Zh on the development and spreading of $A$. alternata on vegetable crops has been shown. After using the product, a decrease in the spreading and development of the pathogen was noted in all studied crops. The maximum decrease in the spreading of alternaria was observed in eggplant, and the maximum decrease in the development of the disease was noted in tomato. At the same time, the spreading of the disease on tomato decreased only compared to the first treatment, while on pepper it remained the same throughout the entire study period. But on these crops a decrease in the development of the disease was noted, which confirms the effectiveness of the biofungicide and shows that it is necessary to take these two indicators into account simultaneously. Analysis of the number of $A$. alternata spores caught with the device in the plantings of the studied crops showed a decrease in the infectious background over the plantings of pepper and eggplant. The number of spores found over tomato plantings after the first treatment increased to 3 pcs. per sample, and after the second treatment it decreased to 2.6 pcs. The number of spores over the plantings of pepper decreased after the first treatment to 0.4 pcs. per sample and did not increase further. No phytopathogen spores were recorded over eggplant plantings after the second treatment. Thus, on the basis of various types of monitoring, the effectiveness of the use of the biofungicide BFTIM KS-2, Zh was proved and its effect on the development and distribution of A. alternata on vegetable crops was shown.

Acknowledgments. The research was carried out with the financial support of the Kuban Science Foundation and the Federal State Budgetary Scientific Institution "Federal Research Center of Biological Plant Protection" within the framework of the scientific project No. MFI-P-20.1/6. 


\section{References}

1. S.N. Nekoval, A.E. Sadovaya, A.V. Belyaeva, Dostizheniya nauki i tekhniki APK, 34, 10, 68-74 (2020) https://doi.org/10.24411/0235-2451-2020-11000

2. A. Salman, A. Kotb, A.I. Ghazy, E.I. Ibrahim, T.K. Al-Ateeq, Saudi J. Biol. Sci., 27, 1, 352-357 (2020) https://doi.org/10.1016/j.sjbs.2019.10.004

3. T. Garcia, J. Veloso, J. Diaz, Eur. J. Plant Pathol., 150, 4, 1091-1101 (2018) https://doi.org/10.1007 / s10658-017-1352-0

4. H.A.S. Alhaithloul, M.S. Attia, M.A. Abdein, Int. J. Bot. Stud., 4, 55-60 (2019)

5. R. Tewari, K. Vishunavat, Int. J. Plant Prot., 5, 201-206 (2012) https://doi.org/10.22271 / chemi.2020.v8.i1p.8415

6. A. Shoaib, Z.A. Awan, K.A. Khan, Sci. Hortic., 252, 20-28 (2019) https://doi.org/10.1016/j.scienta.2019.02.073

7. S. Nekoval, A. Belyaeva, O. Maskalenko, A. Churikova, A. Milovanov, A. Sadovaya, Research on Crops. 21, 3, 545-556 (2020) https://doi.org/10.31830/2348-7542.2020.086

8. K.P. Akhtar, N. Ullah, M.Y. Saleem, Q. Iqbal, M. Asghar, A.R. Khan, JPP, 101, 11591170 (2019) https://doi.org/10.1007/s42161-019-00304-8

9. S.G.A. Moghaddam, Z. Rezayatmand, M.N. Esfahani, M. Khozaei, Plant Physiol. Biochem., 142, 500-509 (2019) https://doi.org/10.1016/j.plaphy.2019.08.011

10. M.J. Soleimani, W. Kirk, J. Plant Prot. Res., 52, 83-90 (2012) https://doi.org/ 10.2478/v10045-012-0014-7

11. O. Kremneva, R. Danilov, O. Tutubalina, I. Sereda, A. Kurilov, BIO Web of Conf., 21, 00002 (2020) https://doi.org/10.1051/bioconf/20202100002

12. R.R. Manda, G. Pavithra, V.A. Addanki, S. Srivastava, Int. J. Curr. Microbiol. App. Sci, 9(11), 749-756 (2020) https://doi.org/10.20546/ijcmas.2020.911.090

13. Yu.G. Sokolov, V.T. Sadkovsky, O.Yu. Kremneva, R.Yu. Danilov, A.A. Pachkin, R.A. Zelensky, A.A. Kurilov, Int.. Res. J., 12-2, 29-33 (2018) https://doi.org/10.23670/IRJ.2018.78.12.042

14. J.S. West, R.B.E. Kimber. Ann. App. Biol., 166, 4-17 (2015) https://doi.org/10.1111/aab.12191

15. D. Savage, M. J. Barbetti, W. J. MacLeod, M. U. Salam, M. Renton, Crop Prot., 36, 2330 (2012) http://dx.doi.org/10.1016/j.cropro.2012.01.015

16. V.I. Dolzhenko, V.N. Rakitsky, Methodical guidelines for registration tests of fungicides in agriculture, 80 (Moscow, FSBSI "Rosinformagrotech", 2019)

17. O.Yu. Kremneva, K.E. Gasiyan, R.A. Zelensky. Rural Machinery and Equipment. 11, 912 (2020) https://doi.org/10.33267/2072-9642-2020-11-9-1 1

18. Ph.B. Gannibal, Monitoring of alternarioses of crops and identification of fungi of the genus Alternaria. A manual, 70 (St. Petersburg, VIZR, 2011) 